\title{
Three-Dimensional Pharmacophore Modeling of Betulonic Acid Derivatives as a Strong Inhibitor of Human Coronavirus-229E Replication
}

\author{
Nilesh S. Kadu ${ }^{1}$, Atul V. Ingle ${ }^{2}$ \\ ${ }^{1}$ Department of Chemistry, Bharatiya Mahavidyalaya, Amravati, Maharashtra, India \\ ${ }^{2}$ Department of Chemistry, Yeshwantrao Chavan College of Arts, Commerce and Science, Sillod, Aurangabad, \\ Maharashtra, India \\ Corresponding Author: Nilesh S. Kadu
}

\begin{abstract}
These-days, pharmacophore approaches have become one of the foremost tools in drug discovery after the past century's development. Numerous ligand-based and structure-based strategies are developed for improved pharmacophore modeling with success and extensively applied in virtual screening, de novo design and lead improvement. Till now, there is little information on 3D-pharmacophore studies of 1,2,3-triazolo-fused betulonic acid derivatives as a strong inhibitor for human coronavirus229 E replication. Here, we tend to report the appliance of pharmacophore modeling for betulonic acid derivatives as an inhibitor. This study has been undertaken to realize intuitions into molecular mechanisms and structural necessities crucial for potential inhibition of betulonic acid derivatives. The standard procedure was adapted to develop the pharmacophoric models. It is found that the pharmacophore model of active betulonic acid derivative (compound 5h) unveils the importance of five- and six-member aliphatic cyclic hydrocarbon moiety, aromatic ring, $-\mathrm{OH}$ group of carboxylic acid, five-member heterocyclic rings (triazolo) and aliphatic alkene group and their correlation with the biological activity. It may be helpful within the design of novel betulonic acid derivatives inhibitors for human coronavirus-229E replication.
\end{abstract}

Keywords: Pharmacophore Model, Antiviral activity, HCoV-229E replication, Betulonic acid derivatives, nsp15.

\section{INTRODUCTION}

Though less explored, the coronavirus (CoV) nsp15 (non-structural protein 15) endoribonuclease (EndoU) is a highly attractive drug target since it has no cellular counterpart, its catalytic site is conserved among CoVs, and it is amenable to structure-based design based on available protein structures. ${ }^{[1-5]}$ The nsp15 is one of the non-structural protein components of the replication-transcription complexes (RTCs), the site where CoV RNA synthesis occurs. ${ }^{[6-}$ ${ }^{8]}$ Although the functions of nsp15 are not entirely understood, its EndoU function is known to regulate viral RNA synthesis, limit the recognition of viral dsRNA by cellular sensors, and prevent the dsRNA activated antiviral host cell response. ${ }^{[9-13]}$ The interferon type I evading activity of nsp15 is well elaborated for mouse coronavirus MHV-A599 and HCoV-229E10 and was recently also demonstrated for SARS-CoV-2. ${ }^{[14]}$ The concept to inhibit nsp15 is thus unique since it combines a direct antiviral effect with the potential to revert viral evasion from host cell immunity.

Recently, Annelies Stevaert et al, ${ }^{[15]}$ reported identification of a class of $\mathrm{HCoV}$ 229E nsp15 inhibitors with a 1,2,3-triazolofused betulonic acid structure. They describe their synthesis, structure-activity relationship (SAR), and the mechanistic findings, in particular resistance data, which 
corroborate nsp15 as the antiviral target for HCoV-229E. Annelies Stevaert et $\mathrm{al},{ }^{[15]}$ discussed the structure-activity relationship exploration of 1,2,3-triazolo-fused betulonic acid derivatives yielded lead molecule as a strong inhibitor (antiviral EC50: $0.65 \mu \mathrm{M}$ ) of $\mathrm{HCoV}-229 \mathrm{E}$ replication. They conclude nsp15 endoribonuclease active site mutant virus was markedly less sensitive to lead molecule and selected resistance to the compound mapped to mutations in the Nterminal part of $\mathrm{HCoV}-229 \mathrm{E}$ nsp 15 , at an interface between two nsp15 monomers. Though, Annelies Stevaert et $\mathrm{al},{ }^{[15]}$ discussed SAR (Structure Activity Relationship), no attempt was investigated to develop the three-dimensional pharmacophore model of betulonic acid derivatives. This is first ever effort to develop the three-dimensional pharmacophore model of betulonic acid derivatives as a strong inhibitor of human coronavirus-229E replication using alignment approach.

Nowadays pharmacophore approaches have become one of the foremost tools in drug discovery after the past century's development. Numerous ligand-based and structure-based strategies are developed for improved pharmacophore modeling with success and extensively applied in virtual screening, de novo design and lead improvement. ${ }^{[16]}$ Pharmacophores are used as queries for recovering likely leads from structural databases for designing molecules with specific desired attributes and for evaluating similarity and variety of molecules manipulation pharmacophore fingerprints. It may be used to align molecules based on the 3D arrangement of chemical structures or to improve prognostic 3D quantitative structural activity relationship (QSAR) models. ${ }^{[17,18]}$ Similarly, Virtual screening is a computational process used in the areas of drug discovery and development to explore libraries of small ligands which can be suitably bound to their target proteins or enzymes while docking is a phenomenon of predicting the orientations of molecules in the bounded stable complex. Till date, there is little information on 3D-pharmacophore studies of betulonic acid derivatives as an inhibitor. Herein, we tend to report the appliance of pharmacophore modeling for betulonic acid derivatives as an inhibitor. This study has been undertaken to realize intuitions into molecular mechanisms and structural necessities crucial for potential inhibition of betulonic acid derivatives. It may be helpful within the design of novel betulonic acid derivatives inhibitors for human coronavirus-229E replication.

\section{MATERIALS \& METHODS Selection of Dataset}

Table-1: SMILES notations and activity values EC50 ( $\mu \mathrm{M})$ of betulonic acid and its most active derivatives used for alignment.

\begin{tabular}{|c|c|c|}
\hline Compounds & SMILES & $\begin{array}{l}\text { Antiviral activity }(\mu \mathrm{M}) \\
\text { EC50 (MTS) }\end{array}$ \\
\hline $\begin{array}{l}\text { Betulonic } \\
\text { acid }\end{array}$ & $\begin{array}{l}\mathrm{C}=\mathrm{C}(\mathrm{C})[\mathrm{C} @ @ \mathrm{H}] 1 \mathrm{CC}[\mathrm{C} @] 2(\mathrm{C}(\mathrm{O})=\mathrm{O}) \mathrm{CC}[\mathrm{C} @ @] 3(\mathrm{C})[\mathrm{C} @] 4(\mathrm{C}) \mathrm{CC}[\mathrm{C} @ @] 5([\mathrm{H}]) \mathrm{C}(\mathrm{C})(\mathrm{C}) \mathrm{C}(\mathrm{CC}[\mathrm{C} @] \\
5(\mathrm{C})[\mathrm{C} @ @] 4([\mathrm{H}]) \mathrm{CC}[\mathrm{C} @] 3([\mathrm{H}])[\mathrm{C} @] 21[\mathrm{H}])=\mathrm{O}\end{array}$ & $>100$ \\
\hline $5 q$ & $\begin{array}{l}\mathrm{C}=\mathrm{C}(\mathrm{C})[\mathrm{C} @ @ \mathrm{H}] 1 \mathrm{CC}[\mathrm{C} @] 2(\mathrm{C}(\mathrm{O})=\mathrm{O}) \mathrm{CC}[\mathrm{C} @ @] 3(\mathrm{C})[\mathrm{C} @] 4(\mathrm{C}) \mathrm{CC}[\mathrm{C} @ @] 5([\mathrm{H}]) \mathrm{C}(\mathrm{C})(\mathrm{C}) \mathrm{C} 6=\mathrm{C} \\
(\mathrm{N}=\mathrm{NN} 6) \mathrm{C}[\mathrm{C} @] 5(\mathrm{C})[\mathrm{C} @ @] 4([\mathrm{H}]) \mathrm{CC}[\mathrm{C} @] 3([\mathrm{H}])[\mathrm{C} @] 21[\mathrm{H}]\end{array}$ & $4.3 \pm 0.6$ \\
\hline $5 \mathrm{r}$ & $\begin{array}{l}\mathrm{C}=\mathrm{C}(\mathrm{C})[\mathrm{C} @ @ \mathrm{H}] 1 \mathrm{CC}[\mathrm{C} @] 2(\mathrm{C}(\mathrm{O})=\mathrm{O}) \mathrm{CC}[\mathrm{C} @ @] 3(\mathrm{C})[\mathrm{C} @] 4(\mathrm{C}) \mathrm{CC}[\mathrm{C} @ @] 5([\mathrm{H}]) \mathrm{C}(\mathrm{C})(\mathrm{C}) \mathrm{C} 6=\mathrm{C} \\
(\mathrm{N}=\mathrm{NN} 6 \mathrm{CC} 7=\mathrm{CC}=\mathrm{CC}=\mathrm{C} 7) \mathrm{C}[\mathrm{C} @] 5(\mathrm{C})[\mathrm{C} @ @] 4([\mathrm{H}]) \mathrm{CC}[\mathrm{C} @] 3([\mathrm{H}])[\mathrm{C} @] 21[\mathrm{H}]\end{array}$ & $0.85 \pm 0.05$ \\
\hline $5 s$ & $\begin{array}{l}\mathrm{C}=\mathrm{C}(\mathrm{C})[\mathrm{C} @ @ \mathrm{H}] 1 \mathrm{CC}[\mathrm{C} @] 2(\mathrm{C}(\mathrm{O})=\mathrm{O}) \mathrm{CC}[\mathrm{C} @ @] 3(\mathrm{C})[\mathrm{C} @] 4(\mathrm{C}) \mathrm{CC}[\mathrm{C} @ @] 5([\mathrm{H}]) \mathrm{C}(\mathrm{C})(\mathrm{C}) \mathrm{C} 6=\mathrm{C}(\mathrm{N}= \\
\mathrm{NN}=[\mathrm{C} @ \mathrm{H}](\mathrm{C}) \mathrm{C} 7=\mathrm{CC}=\mathrm{CC}=\mathrm{C} 7) \mathrm{C}[\mathrm{C} @] 5(\mathrm{C})[\mathrm{C} @][4([\mathrm{H}]) \mathrm{CC}[\mathrm{C} @] 3([\mathrm{H}])[\mathrm{C} @] 21[\mathrm{H}]\end{array}$ & $1.1 \pm 0.2$ \\
\hline $5 \mathrm{t}$ & $\begin{array}{l}\mathrm{CC}(\mathrm{C})[\mathrm{C} @ @ \mathrm{H}] 1 \mathrm{CC}[\mathrm{C} @] 2(\mathrm{C}(\mathrm{O})=\mathrm{O}) \mathrm{CC}[\mathrm{C} @ @] 3(\mathrm{C})[\mathrm{C} @] 4(\mathrm{C}) \mathrm{CC}[\mathrm{C} @ @] 5([\mathrm{H}]) \mathrm{C}(\mathrm{C})(\mathrm{C}) \mathrm{C} 6=\mathrm{C}(\mathrm{N}=\mathrm{NN} 6 \\
[\mathrm{C} @ \mathrm{H}](\mathrm{C}) \mathrm{C} 7=\mathrm{CC}=\mathrm{CC}=\mathrm{C} 7) \mathrm{C}[\mathrm{C} @] 5(\mathrm{C})[\mathrm{C} @ @] 4([\mathrm{H}]) \mathrm{CC}[\mathrm{C} @] 3([\mathrm{H}])[\mathrm{C} @] 21[\mathrm{H}]\end{array}$ & $13 \pm 5$ \\
\hline $5 u$ & $\begin{array}{l}\mathrm{C}=\mathrm{C}(\mathrm{C})[\mathrm{C} @ @ \mathrm{H}] 1 \mathrm{CC}[\mathrm{C} @] 2(\mathrm{C}) \mathrm{CC}[\mathrm{C} @ @] 3(\mathrm{C})[\mathrm{C} @] 4(\mathrm{C}) \mathrm{CC}[\mathrm{C} @ @] 5([\mathrm{H}]) \mathrm{C}(\mathrm{C})(\mathrm{C}) \mathrm{C} 6=\mathrm{C}(\mathrm{N}=\mathrm{NN} 6 \\
[\mathrm{C} @ \mathrm{H}](\mathrm{C}) \mathrm{C} 7=\mathrm{CC}=\mathrm{CC}=\mathrm{C} 7) \mathrm{C}[\mathrm{C} @] 5(\mathrm{C})[\mathrm{C} @ @] 4([\mathrm{H}]) \mathrm{CC}[\mathrm{C} @] 3([\mathrm{H}])[\mathrm{C} @] 21[\mathrm{H}]\end{array}$ & $>100$ \\
\hline $5 \mathrm{~h}$ & $\begin{array}{l}\mathrm{C}=\mathrm{C}(\mathrm{C})[\mathrm{C} @ @ \mathrm{H}] 1 \mathrm{CC}[\mathrm{C} @] 2(\mathrm{C}(\mathrm{O})=\mathrm{O}) \mathrm{CC}[\mathrm{C} @ @] 3(\mathrm{C})[\mathrm{C} @] 4(\mathrm{C}) \mathrm{CC}[\mathrm{C} @ @] 5([\mathrm{H}]) \mathrm{C}(\mathrm{C})(\mathrm{C}) \mathrm{C} 6=\mathrm{C}(\mathrm{N}=\mathrm{NN} 6 \\
[\mathrm{C} @ \mathrm{H}](\mathrm{C}) \mathrm{C} 7=\mathrm{CC}=\mathrm{CC}=\mathrm{C} 7) \mathrm{C}[\mathrm{C} @] 5(\mathrm{C})[\mathrm{C} @ @] 4([\mathrm{H}]) \mathrm{CC}[\mathrm{C} @] 3([\mathrm{H}])[\mathrm{C} @] 21[\mathrm{H}]\end{array}$ & \pm 0.08 \\
\hline
\end{tabular}

The dataset includes twenty-three 1,2,3-triazolo-fused betulonic acid scaffold derivatives exhibiting the antiviral activity
(EC50) in $\mu \mathrm{M}$ range. Almost all betulonic acid derivatives proved to be highly effective $\mathrm{CoV}$ inhibitors. ${ }^{[15]}$ The betulonic 
acid derivatives possess good variation in substation pattern like the presence of carboxylic acid moiety, 1,2,3-triazole moiety, aliphatic and aromatic moieties. They also possess hydrophobic interactions and hydrogen-bonding interactions. ${ }^{[15]}$ Therefore, the selected dataset is wide enough to develop a pharmacophore model of betulonic acid derivatives. Out of these the dataset of betulonic acid and its six most active derivatives have been tabulated in table 1 .

\section{Development of Pharmacophore Model}

All computations were performed on different types of software such as ChemSketch 2010 freeware, MOPAC 2012, Open3DAlign and Forge 10.0.1. The standard procedure used in the present work for developing consensus pharmacophore model involves recommended steps in the literature. ${ }^{[19-23]}$ The four main steps for generating pharmacophore model of betulonic acid derivatives are:

a) Drawing the structures using a software (ChemSketch 2010 freeware)

b) Optimization using a suitable method (MOPAC 2012 using AM1 method)

c) Aligning all the molecules in the dataset using suitable approach (Open3DAlign software)

d) Generation of a consensus pharmacophore model (Forge 10.0.1 software)

\section{RESULT AND DISCUSSION}

Pharmacophore models represent the 3D-arrangement of the chemical features and steric limitations that are necessary for a small molecule to interact with a specific target protein. ${ }^{[2]}$ These features correspond to chemical functionalities such as hydrogen bond acceptors (HBAs), hydrogen bond donors (HBDs), hydrophobic areas (Hs), aromatic rings (ARs) and positively/negatively ionizable groups (PIs/NIs). In the present study, the chemical features of six most active betulonic acid derivatives (Compound 5q, 5r, 5s, 5t, 5u and 5h) are analyzed. Among these, the pharmacophore model provides strong evidence that the lead molecule $5 \mathrm{~h}$ as a strong inhibitor (antiviral EC50: $0.65 \mu \mathrm{M}$ ) of HCoV-229E replication. The pharmacophore model of lead molecule $5 \mathrm{~h}$ (betulonic acid derivative) is represented in fig. 1. The pharmacophoric pattern of betulonic acid derivative (lead molecule $5 \mathrm{~h}$ ) is highlighted by four contour regions. Yellow colour region represented lipophilic nature i.e., van der Waals surface field points, gold or orange colour represented hydrophobic field points, blue colour region represented negative field points and red colour region represented positive field points of the compound. The present pharmacophore analysis reveals that the activity of betulonic acid derivative (lead molecule 5h) has good correlation with these three contour portions.

A representative field point pattern of lead molecule $5 \mathrm{~h}$ is shown in fig. 1 . The size of the point indicates the potential strength of the interaction. Larger field points represent stronger points of potential interaction while the smaller field points represent weaker point of potential interaction. On the basis of size of the point, it is seen that, $5 \mathrm{~h}$ molecule shows three types of negative field points (blue colour). Larger blue colour field point (negative ionic field) is present over 1,2,3-triazole moiety, indicates that these ionic group has strong tendency to interact positive ionic group. Smaller blue colour field point is present above and below the aromatic moiety and aliphatic alkene group implies that these groups have negative $\pi$-cloud and have less tendency to $\mathrm{H}$-bond acceptor. Intermediary (between large and small size) blue colour field point is present over carbonyl ligand, indicate that these negative field group has tendency to H-bond acceptor.

On the other hand, it is observed that, $5 \mathrm{~h}$ molecule shows only two positive field points (red colour) as compared to negative field points. This molecule does not show larger red colour field point (positive ionic field) indicating less 
tendency to attract negative ionic group. The intermediate size (between large and small) red colour field is present over 1,2,3triazole moiety and $-\mathrm{OH}$ group of carboxylic acid indicate that these moieties have tendency to H-bond donor. Smaller red colour field point is present over the aromatic moiety which indicates aromatic ring having less tendency to $\pi$-H-bond donor.

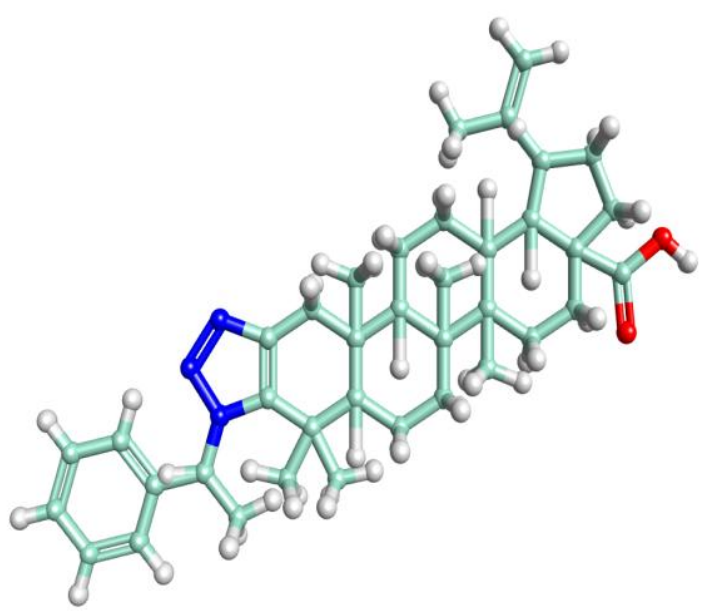

(a)

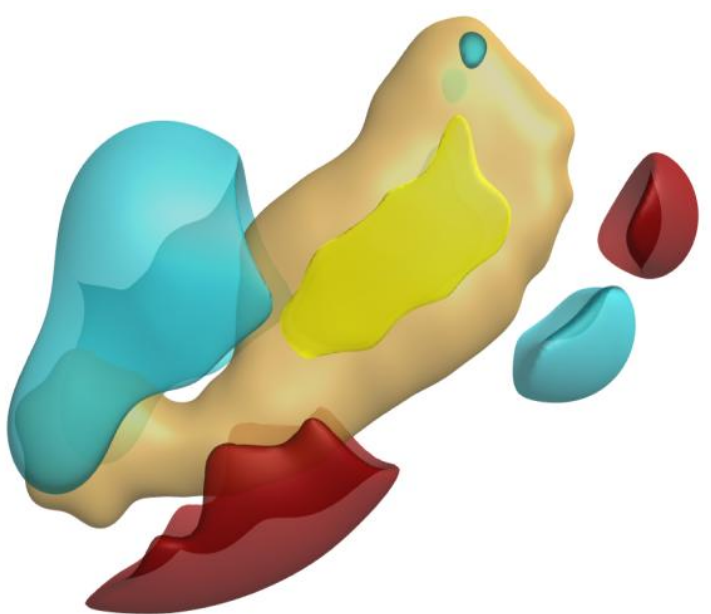

(b)

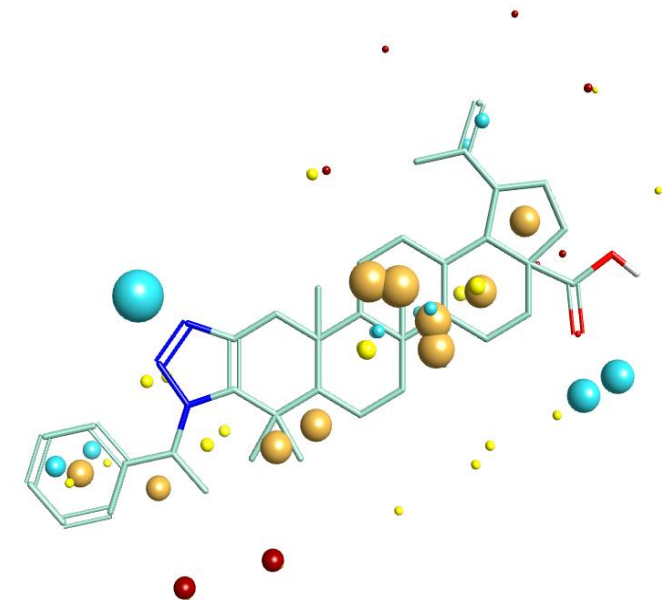

(c)

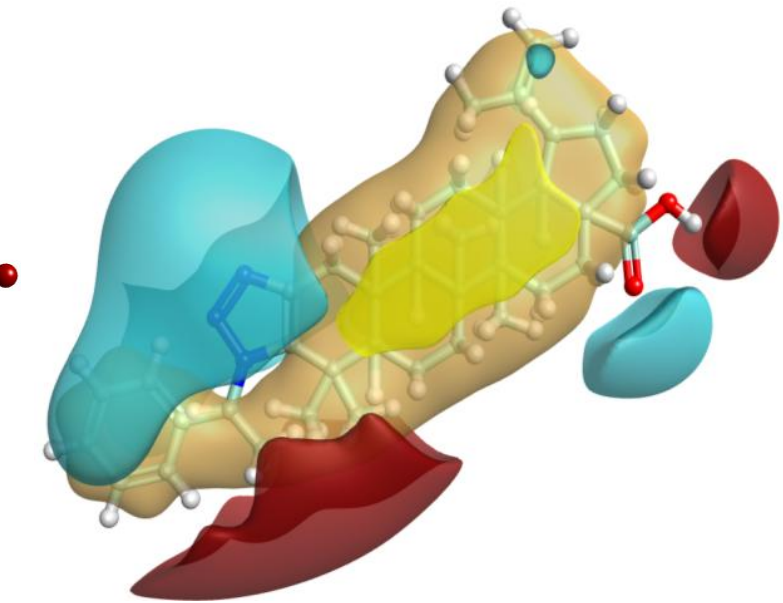

(d)

Fig. -1: Activity of betulonic acid derivative (lead molecule 5h). (a) 3D-structure of 5 h molecule. (b) Four contour regions of 5h molecule. (c) Interpretation of the different field types around $5 \mathrm{~h}$ molecule. (d) Three-dimensional representation of pharmacophoric pattern for $5 \mathrm{~h}$ molecule.

It is observed that, $5 \mathrm{~h}$ molecule is strongly hydrophobic in nature (shown by gold or orange colour field). This hydrophobic field is due to presence of fiveand six-member aliphatic cyclic hydrocarbon ring, aromatic ring and aliphatic group in $5 \mathrm{~h}$ molecule. The strong hydrophobic nature of $5 \mathrm{~h}$ molecule indicates high polarizability and hydrophobicity. It is also seen that, 5h molecule has highly lipophilic nature (shown by yellow colour field). This lipophilic nature represents van der Waals interactions in 5h molecule, which is due to the presence of aliphatic hydrocarbon ring, aromatic ring and aliphatic groups. This lipophilic nature describes the stickiest surface of $5 \mathrm{~h}$ molecule.

Thus, pharmacophore model of 1,2,3-triazolo-fused betulonic acid derivative (compound 5h) shows the importance of five- and six-member aliphatic cyclic hydrocarbon moiety, aromatic ring, $-\mathrm{OH}$ group of carboxylic acid, five-member heterocyclic rings (triazolo) and aliphatic alkene group and their correlation with the biological activity. Hence such a combination of these moieties 
must be retained in future optimization to have good activity.

\section{CONCLUSION}

The present work reveals important pharmacophoric patterns of betulonic acid derivatives inhibitors for human coronavirus-229E replication. The produced pharmacophore reflects four primary features; hydrogen bond acceptors (HBAs), hydrogen bond donors (HBDs), hydrophobic areas (Hs), positively ionizable groups (PIs) and negatively ionizable groups (NIs). Ionic groups give rise to the strongest electrostatic fields. Hydrogen bonding groups also give strong electrostatic fields. Aromatic groups encode both electrostatic and hydrophobic fields. Aliphatic cyclic groups highlight hydrophobic and surface points but are essentially electrostatically neutral. In future, this pharmacophore models will assist to discover new inhibitors for human coronavirus-229E replication.

\section{Acknowledgement: None}

\section{Conflict of Interest: None}

\section{Source of Funding: None}

\section{REFERENCES}

1. Ricagno, S.; Egloff, M. P.; Ulferts, R.; Coutard, B.; Nurizzo, D.; Campanacci, V.; Cambillau, C.; Ziebuhr, J.; Canard, B. Crystal structure and mechanistic determinants of SARS coronavirus nonstructural protein 15 define an endoribonuclease family. Proc. Natl. Acad. Sci. U. S. A. 2006, 103, 11892-11897.

2. Huo, T.; Liu, X. Crystallization and preliminary X-ray crystallographic analysis of a nonstructural protein 15 mutants from Human coronavirus 229E. Acta Crystallogr. Sect. F Struct. Biol. Cryst. Commun. 2015, 71, 1156-1160.

3. Kim, Y.; Jedrzejczak, R.; Maltseva, N. I.; Wilamowski, M.; Endres, M.; Godzik, A.; Michalska, K.; Joachimiak, A. Crystal structure of Nsp15 endoribonuclease NendoU from SARS-CoV-2. Protein Sci. 2020, 29, 1596-1605.
4. Xu, X.; Zhai, Y.; Sun, F.; Lou, Z.; Su, D.; Xu, Y.; Zhang, R.; Joachimiak, A.; Zhang, X. C.; Bartlam, M.; Rao, Z. New antiviral target revealed by the hexameric structure of mouse hepatitis virus nonstructural protein nsp15. J. Virol. 2006, 80, 7909-7917.

5. Zhang, L.; Li, L.; Yan, L.; Ming, Z.; Jia, Z.; Lou, Z.; Rao, Z. Structural and biochemical characterization of endoribonuclease Nsp15 encoded by Middle East Respiratory Syndrome Coronavirus. J. Virol. 2018, 92, e00893-e00918.

6. Fehr, A. R.; Perlman, S. Coronaviruses: an overview of their replication and pathogenesis. Methods Mol. Biol. 2015, 1282, 1-23.

7. Sevajol, M.; Subissi, L.; Decroly, E.; Canard, B.; Imbert, I. Insights into RNA synthesis, capping, and proofreading mechanisms of SARS-coronavirus. Virus Res. 2014, 194, 90-99.

8. V'Kovski, P.; Kratzel, A.; Steiner, S.; Stalder, H.; Thiel, V. Coronavirus biology and replication: implications for SARSCoV-2. Nat. Rev. Microbiol. 2021, 19, 155-170.

9. Deng, X.; Hackbart, M.; Mettelman, R. C.; O'Brien, A.; Mielech, A. M.; Yi, G.; Kao, C. C.; Baker, S. C. Coronavirus nonstructural protein 15 mediates evasion of dsRNA sensors and limits apoptosis in macrophages. Proc. Natl. Acad. Sci. U. S. A. 2017, 114, E4251-E4260.

10. Kindler, E.; Gil-Cruz, C.; Spanier, J.; Li, Y.; Wilhelm, J.; Rabouw, H. H.; Züst, R.; Hwang, M.; V'Kovski, P.; Stalder, H.; Marti, S.; Habjan, M.; Cervantes-Barragan, L.; Elliot, R.; Karl, N.; Gaughan, C.; van Kuppeveld, F. J.; Silverman, R. H.; Keller, M.; Ludewig, B.; Bergmann, C. C.; Ziebuhr, J.; Weiss, S. R.; Kalinke, U.; Thiel, V. Early endonuclease-mediated evasion of RNA sensing ensures efficient coronavirus replication. PLoS Pathog. 2017, 13, No. e1006195.

11. Hackbart, M.; Deng, X.; Baker, S. C. Coronavirus endoribonuclease targets viral polyuridine sequences to evade activating host sensors. Proc. Natl. Acad. Sci. U. S. A. 2020, 117, 8094-8103.

12. Ancar, R.; Li, Y.; Kindler, E.; Cooper, D. A.; Ransom, M.; Thiel, V.; Weiss, S. R.; Hesselberth, J. R.; Barton, D. J. Physiologic RNA targets and refined sequence 
specificity of coronavirus EndoU. RNA. 2020, 26, 1976-1999.

13. Deng, X.; Baker, S. C. An "Old" protein with a new story: Coronavirus endoribonuclease is important for evading host antiviral defenses. Virology. 2018, 517, 157-163.

14. Yuen, C. K.; Lam, J. Y.; Wong, W. M.; Mak, L. F.; Wang, X.; Chu, H.; Cai, J. P.; Jin, D. Y.; To, K. K.; Chan, J. F.; Yuen, K. Y.; Kok, K. H. SARS-CoV-2 nsp13, nsp14, nsp15 and orf6 function as potent interferon antagonists. Emerging Microbes Infect. 2020, 9, 1418-1428.

15. Stevaert, A.; Krasniqi, B.; Van Loy, B.; Nguyen, T.; Thomas, J.; Vandeput, J.; Jochmans, D.; Thiel, V.; Dijkman, R.; Dehaen, W.; Voet, A.; Naesens, L. Betulonic Acid Derivatives Interfering with Human Coronavirus 229E Replication via the nsp15 Endoribonuclease. J. Med. Chem. 2021, 64, 5632-5644.

16. Yang, S. Y. Pharmacophore modeling and applications in drug discovery: challenges and recent advances. Drug Discovery Today. 2010, 15, 440-450.

17. Kadu, N.S.; Ingle, A.V.; Bansod, P.G.; Gawhlae, N.D.; Suryawanshi, S.B. Investigation of ADMET Profile of Lead Molecule for COVID-19. IJRASET. 2020, 8(7), 1733-1735.

18. Masand, V. H.; El-Sayed, N. N. E.; Mahajan, D. T.; Mercader, A. G.; Alafeefi, A. M.; Shibi, I. G. QSAR modeling for antihuman African trypanosomiasis activity of substituted 2-Phenylimidazopyridines. J. Mol. Stru. 2017, 1130, 711-718.
19. Kadu, N.S. Pharmacophore Modeling for AG-270, a First-in-Class Oral MAT2A Inhibitor for the Treatment of Tumours with Homozygous MTAP Deletion. IJRASET. 2021, 9(5) 877-880.

20. Kadu, N.S. Pharmacophore Modeling for Anti-Parasitic Activity of 2Nitroimidazopyrazin-one/-Es. Research Journey. 2019, 110, 248-251.

21. Gao, Q.; Yang, L.; Zhu, Y. Pharmacophore based drug design approach as a practical process in drug discovery. Curr. Comput. Aided Drug Des. 2010, 6, 37-49.

22. Kadu, N.S. Structure-activity relationship: Study of LEI-401 as inhibitor of NAPEPLD by pharmacophore model. Int. J. Adv. Res. 2021, 9(05), 662-666.

23. Kadu, N.S.; Kalyamwar, V.S. Study of Additional Interactions of Heterodimeric GW7604 Derivatives at the Coactivator Binding Site through Pharmacophore Modeling. IJRASET. 2021, 9(6) 214-219.

24. Wermuth, C. G.; Ganellin, C. R.; Lindberg, P.; Mitscher, L. A. Glossary of terms used in medicinal chemistry (IUPAC Recommendations). Pure Appl. Chem. 1998, 70, 1129-1143.

How to cite this article: Kadu NS, Ingle AV. Three-dimensional pharmacophore modeling of betulonic acid derivatives as a strong inhibitor of human Coronavirus-229E replication. International Journal of Science \& Healthcare Research. 2021; 6(2): 356-361. DOI: https://doi. org/10.52403/ijshr.20210462 